\title{
Subsurface investigations of landslides using geophysical methods - geoelectrical applications in the Swabian Alb (Germany)
}

\author{
Rainer Bell, Jan-Erik Kruse, Alejandro Garcia, Tho- \\ mas Glade, Bonn, Andreas Hördt, Braunschweig
}

\section{Introduction}

Landslides may be considered as common natural hazards, in many cases leading to significant economic losses and even fatalities. Since recent landslide activities in many regions often result from reactivations of old landslides, it is important to detect and investigate older landslides in more detail in order to gain insight into landsliding processes characteristic for a particular region. Such information could possibly be used to improve current landslide hazard assessment.

Reliable information on the extent, structure, sliding plane location, moisture conditions, ground water table and the degree of activity are essential for the careful assessment of landslide hazards. Traditional techniques (e.g. drillings) are expensive and often not suitable for the rugged terrain of a landslide. In addition, such investigations only provide point information. In contrast, geophysical methods are much cheaper and faster, having the added bonus of delivering 2D or even 3D information. According to McCANN \& Forster (1990), it would appear that geophysical methods can deliver the necessary information for hazard assessment of landslides. An overview on the applicability of geophysical methods for geomorphology is to be found in Schrotr et al. (2003).

In landslide studies, geophysical methods have been successfully applied over the last forty years, making use of resistivity (e.g. Denness et al. 1975; Donnelly et al. 2005), self-potential (e.g. LAPENNA et al. 2005), low frequency electromagnetics (e.g. ScHmutz et al. 2000), ground-penetrating radar (e.g. RocH et al. 2005), seismic methods (e.g. BogoslovsKy \& OgILvy 1977; Glade et al. 2005), and gravity (e.g. Del Gaudio et al. 2000). Several studies exist comparing different geophysical methods (see Bichler et al. 2004; Cutlac \& Maillol 2004; Sass et al.). From these, it is apparent that each method has its specific field of application, as well as its limitations (Tab. 1). Thus, a combination of various methods would seem appropriate for the investigation of complex structured landslides. Despite the improvements made in the implementation of geophysical methods however, it is still crucial to support geophysical evidence with general geological and detailed borehole information in order to obtain a more complete picture of the subsurface.
A typical problem area in the interpretation of results relates to the variation of characteristic values within one material. As intrinsic variation is often greater than variation between materials, large overlapping of results can occur, in many cases preventing a definite correlation of investigated values with specific materials. With reference to resistivity, moisture content would be the main factor causing heightened intrinsic variation. As moisture content is a valuable aspect of landslide research, this is not necessarily a disadvantage of the method. Soil moisture studies have been carried out, for example, by BogosLovsky \& OgILvy (1977), SuZuKi \& Higashi (2001) and HanAFy \& AL Hagrey (2006).

This study explores the hypothesis that 2D resistivity allows identification of extent of recent landslide activity, of new and old landslide body structure (including the location of the sliding plane/s) and enables the monitoring of moisture distribution within a landslide. The potentials and limitations of the method are addressed.

\section{Study area}

For the purposes of this research project, the Unterhausen landslide with an approximate extent of $0.5 \mathrm{~km}^{2}$ was investigated. It is located in the Central Swabian Alb (Fig. 1), a cuesta landscape composed of Jurassic sedimentary rocks (limestone overlying marls and clays). The average annual temperature is about $9^{\circ} \mathrm{C}$ and average rainfall ranges between 800 and $1000 \mathrm{~mm}$. The settlement of the study area started in the early 1970 s.

The extent of the old rotational landslide as mapped by Dongus (1977) is shown on Fig. 2. Damage on one of the houses is an indication that at least parts of the old landslide mass are occasionally reactivated. Results from the drillings and inclinometers taken at Lic01-03 indicate that the boundary of the reactivated landslide could be between Lic01 and Lic02. Movement within the landslide appears to be rather complex. In late summer and early autumn 2005, a slow flowing movement was detected until a depth of $8.50 \mathrm{~m}$ (in borehole/inclinometer Lic02). During the extensive and rapid snowmelt in spring 2005, a sliding movement until a depth of $15.50 \mathrm{~m}$ was observed. Some of the massive limestone blocks from the escarpment fell down, stopping within the forested area upslope of the settlement. This deposition area appears to be the old landslide head. 


\begin{tabular}{|c|c|c|c|c|c|c|c|c|}
\hline \multicolumn{2}{|l|}{ Methods } & $\begin{array}{l}\text { Rock } \\
\text { slides }\end{array}$ & Soil slides & $\begin{array}{l}\text { Quick clay } \\
\text { landslides }\end{array}$ & $\begin{array}{l}\text { Rock } \\
\text { falls }\end{array}$ & $\begin{array}{l}\text { Property } \\
\text { determination } \\
\text { for } \\
\text { geotechnical } \\
\text { purposes }\end{array}$ & $\begin{array}{l}\text { e.g. artefacts, } \\
\text { pipes, } \\
\text { foundations }\end{array}$ & $\begin{array}{l}\text { Ground } \\
\text { water/soil } \\
\text { moisture }\end{array}$ \\
\hline \multirow{4}{*}{$\begin{array}{l}\text { Seismic } \\
\text { methods }\end{array}$} & Refraction/Reflection & + & + & + & $?$ & + & $-1(+)$ & $+1-$ \\
\hline & Tomography & + & + & - & - & + & $(+)$ & - \\
\hline & Passive seismic & + & + & - & + & - & & - \\
\hline & Surface waves & $?$ & $?$ & + & - & + & & - \\
\hline \multirow{2}{*}{$\begin{array}{l}\text { Electro- } \\
\text { magnetic } \\
\text { methods } \\
(\mathrm{EM})\end{array}$} & Low frequency & + & + & - & - & - & + & + \\
\hline & $\begin{array}{l}\text { Ground-penetrating } \\
\text { radar (GPR) }\end{array}$ & + & $\begin{array}{l}+ \\
\text { (depends } \\
\text { on clay } \\
\text { content) }\end{array}$ & - & + & - & + & + \\
\hline \multicolumn{2}{|c|}{ Resistivity measurements } & + & + & + & $?$ & - & $(+)$ & + \\
\hline \multicolumn{2}{|c|}{ Self-potential (SP) } & + & + & - & - & - & - & + \\
\hline \multicolumn{2}{|c|}{ Induced polarisation (IP) } & - & - & + & - & - & - & + \\
\hline \multicolumn{2}{|c|}{ Gravity } & $?$ & $?$ & - & + & + & - & - \\
\hline \multicolumn{2}{|c|}{ Magnetism } & $?$ & $?$ & - & - & - & & - \\
\hline
\end{tabular}

$+=$ suitable,$(+)=$ partially suitable,$-=$ not suitable, $?=$ depends on the site or needs further analysis

Tab. 1: Suitability of various geophysical methods for different landslide types and landslide related features Eignung verschiedener geophysikalischer Methoden für unterschiedliche Typen von gravitativen Massenbewegungen und damit verbundene Aspekte

Pertinence de différentes méthodes géophysiques selon les différents types de glissements de terrain et caractéristiques associées

Source: BouILLON (2005) and HACK (2000) (modified and adapted)

\section{Methods}

\subsection{Drillings}

To get information on the material and structure of the subsurface, three drillings were carried out at different locations (Fig. 2). Here, only the results of Lic02 are presented. The drilling was contracted to Goller Bohrtechnik, which used rotary drilling to extract a disturbed core with a diameter of $120 \mathrm{~mm}$.

\subsection{Direct current (DC) resistivity}

Based on the findings of a previous study (SASS et al.), the selection of the main geophysical method fell on 2D resistivity tomography. This resistivity method makes use of different resistivity values specifically characteristic to individual subsurface materials. Once subsurface resistivity distribution is established, this information can be related to characteristic resistivity values of the individual materials, allowing finally, an interpretation of the possible structure of the subsurface. Examples of typical resistivity values may be found, for example, in REYNOLDS (1997) and KNÖDEL et al. (1997).

Results were obtained as follows: A constant current was sent through two current electrodes of a multielectrode array in the ground. Two potential electrodes were used to measure the resulting voltage differences. Measurements were carried out with different electrode array configurations in order to provide a tomography-like resolution. Finally, distribution of subsurface resistivity in $2 \mathrm{D}$ could be established by inverting resistivity values (LOKE \& BARKER 1995). Refer to REYNOLDS (1997) or KNöDEL et al. (1997) for further details on the approach.

For this study, an ABEM Lund imaging system with a Terrameter 300 device was used. All profiles were measured applying Wenner array geometry. During the course of the year, three profiles were laid: two in a forest in exactly the same location to allow for investigation of different situational influences, and the third longitudinal to the slope to determine the subsurface structure of the landslide at the location where movements caused damage on the house (Fig. 2). The profiles can be characterised as follows:

- Forest Profile 1: 41 electrodes, $5 \mathrm{~m}$ electrode spacing, $200 \mathrm{~m}$ length, penetration depth approximately $33 \mathrm{~m}$, current $0.2 \mathrm{~mA}, 12 / 04 / 2005$, after a period of heavy snowmelt.

- Forest Profile 2: 41 electrodes, $5 \mathrm{~m}$ electrode spacing, $200 \mathrm{~m}$ length, penetration depth approximately $33 \mathrm{~m}$, current $0.2 \mathrm{~mA}, 17 / 06 / 2005$.

- Longitudinal Profile 1: 61 electrodes, 3 m electrode spacing, $180 \mathrm{~m}$ length, penetration depth approximately $20 \mathrm{~m}$, current $5-10 \mathrm{~mA}, 13 / 12 / 2005$. 


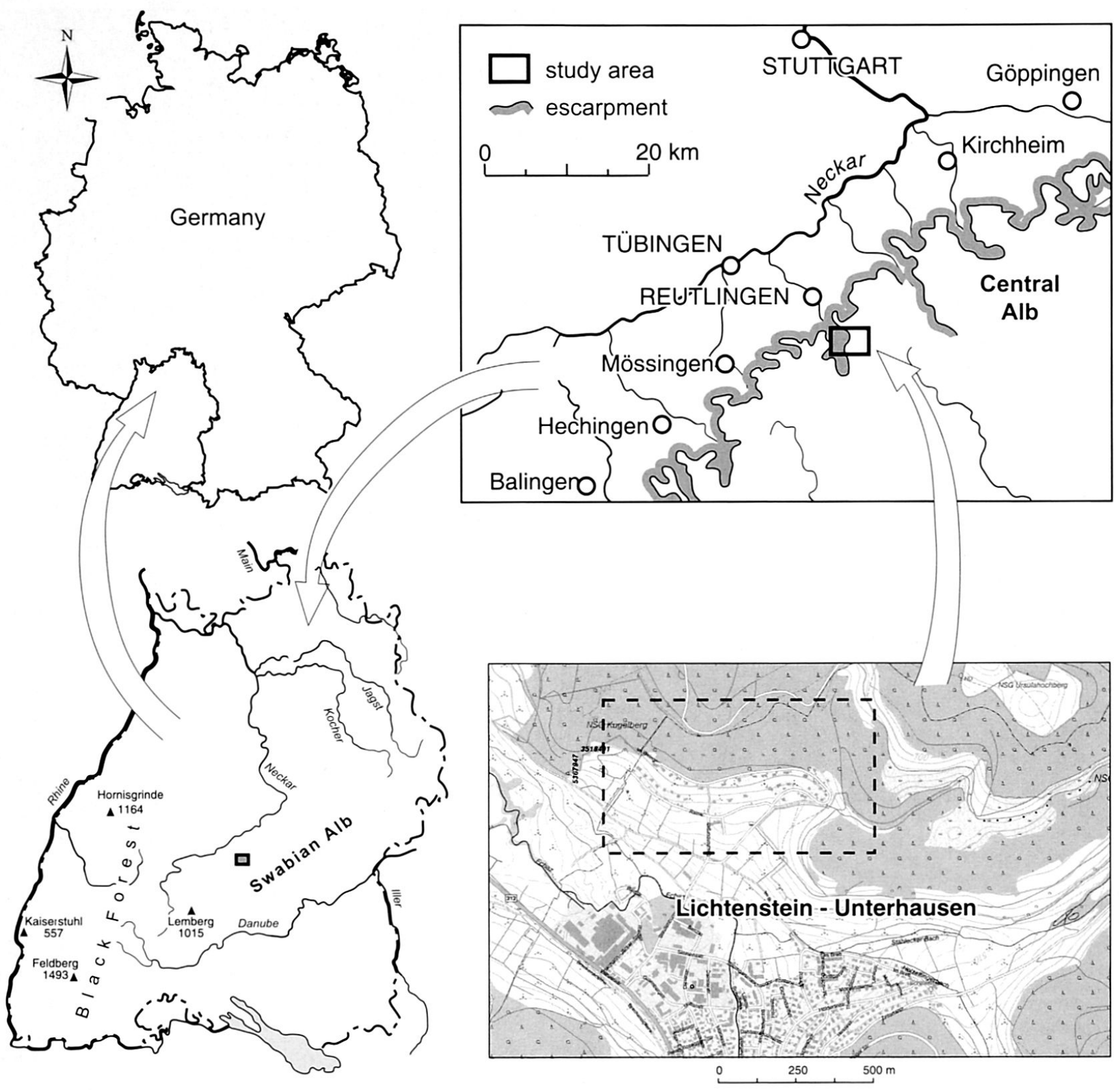

Fig. 1: Location of the study area

Lage des Untersuchungsgebietes

Localisation de la zone d'étude

Source: RK10 (Raster map 1:10000), () 2006 Landesvermessungsamt Baden-Württemberg, AZ: 2851.2D/5270 (reprinted with permission); Draft and cartography: R. BELL

Data inversion was carried out using the software programme RES2DINV (LOKE \& BARKER 1995), particularly as it allowed the inclusion of data on the local topography for data processing. The inversion routine used by RES2DINV is based on the smoothness-constrained least-squares method. For Longitudinal Profile 1, besides standard inversion (Profile 1a), a model run-through was made including results of borehole Lic02 and assuming horizontally elongated structures (Profile 1b). The latter routine alternative minimises absolute changes in resistivity values, thereby enabling a clearer contrast between interfaces of different resistivity regions (Gеотомо 2004). Additionally, the inversion was constrained by a vertical to horizontal flatness filter ratio setting of 0.5 and a bedrock depth of $15.15 \mathrm{~m}$ at the location of borehole LIC02. This too, created a sharper boundary at this depth. 


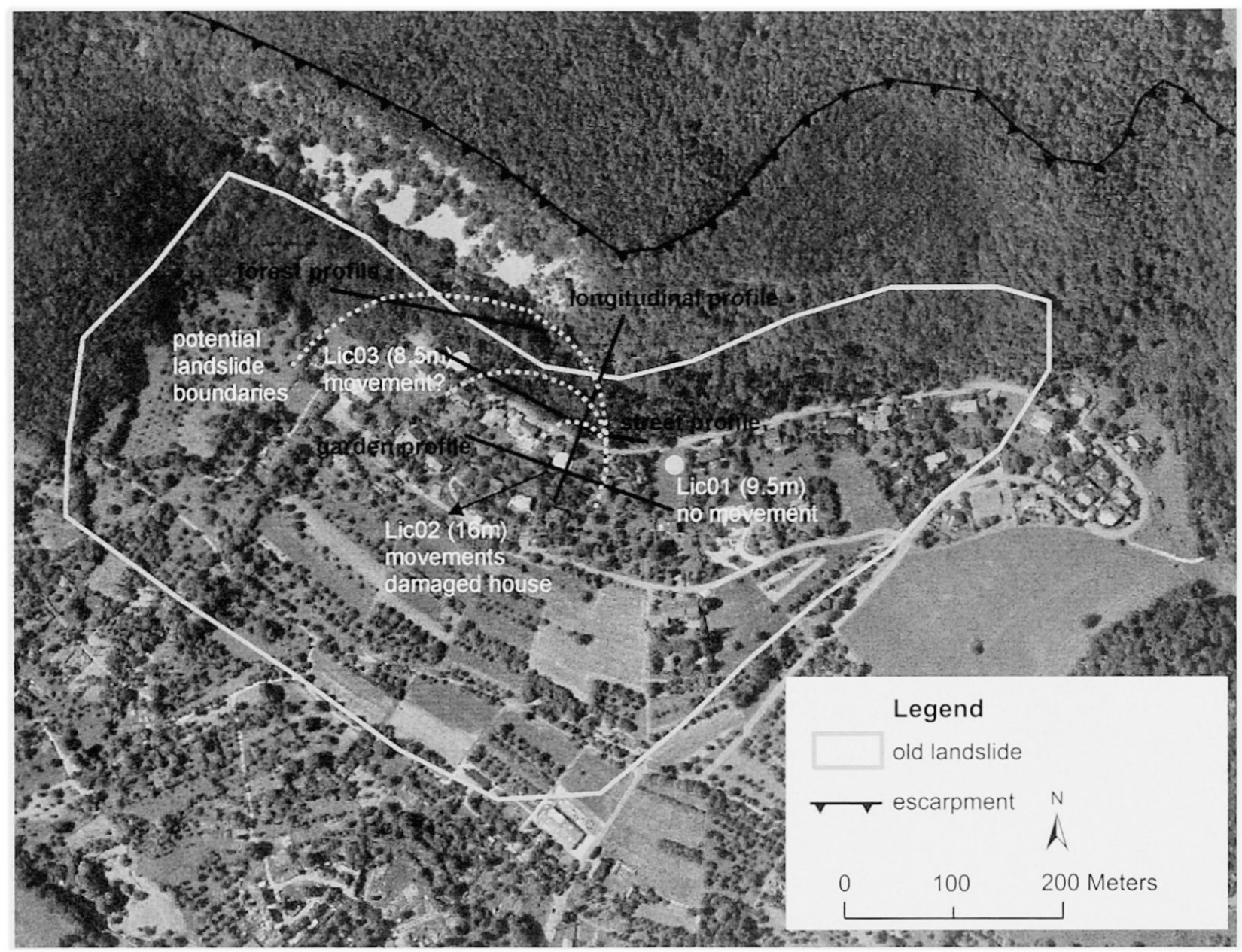

Fig. 2: Comparison of extent of old landslide activity, as mapped by Dongus (1977) at a scale of 1:50000, and recent landslide activities. Locations of recent investigation sites are indicated.

Grenzen der alten Hangrutschungen (kartiert im Massstab 1:50000 von Dongus 1977) und der jüngeren Hangrutschungsaktivitäten. Zusätzlich sind die Lokalitäten der aktuellen Untersuchungen dargestellt.

Carte de l'extension de l'ancien glissement de terrain (cartographié au 1:50000 par Dongus 1977) et des glissements plus récents. Les sites d'investigation sont indiqués.

Source: Digital terrain model (DTM), digital orthophoto (DOP), @ LANDESVERMESSUNGSAMT BADEN-WürTtEMBERG, AZ: 2851.9-1/11 (reprinted with permission); Draft and cartography: R. BELL

\section{Results}

\subsection{Drilling}

The Lic 02 core of $16.00 \mathrm{~m}$ reached claystone bedrock at a depth of $15.15 \mathrm{~m}$. The core material stemmed from the old landslide, consisting mainly of gravelly clay with interbedded weathered marl.

\subsection{DC resistivity}

The calculated inversion models show an immanent error (RMS-error) that ranges between 2.2 and 7.9. Consequently, the results can be classified as good and reliable.

Forest Profile 1 on the whole has very low resistivity values around $20 \Omega \mathrm{m}$ (Fig. 3a). Only in the lower western part are resistivity values very high. SASS et al., in a similar environmental setting linked high resistivity of around $300 \Omega \mathrm{m}$ and more with limestone blocks, the surrounding clays and marls showing much lower restistivities. This could possibly be the situation in the research area described here, the limestone blocks either being a part of the old landslide mass or having been introduced later through rock fall. Similarly, the lower resistivity values in this profile may represent either marls and/or clay. There appears to be a sliding plane at a depth of 15 to $20 \mathrm{~m}$.

The 2D of Forest Profile 2 seems to be quite different (Fig. 3b). Low resistivities, like those observed in 
a) 0 Model resistivity with topography Iteration 6 Abs. error $=4.1$

Forest Profile, 07.04.2005

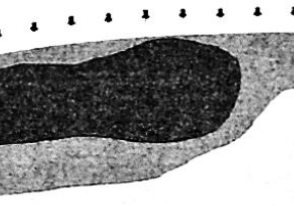

$-20$

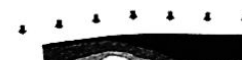

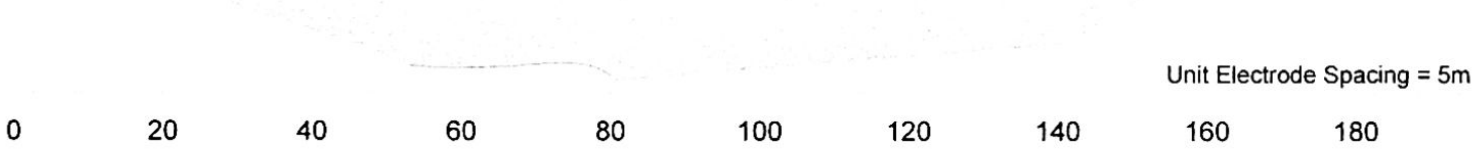

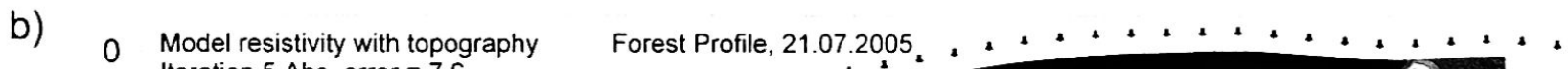
Iteration 5 Abs. error $=7.6$

$-20$

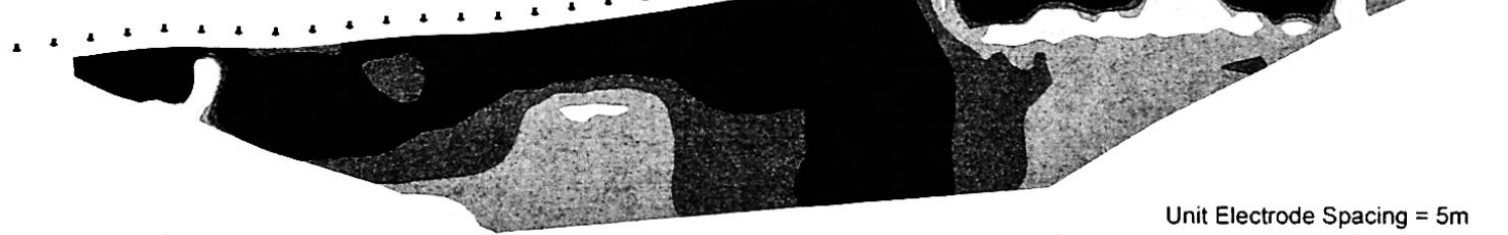

$\begin{array}{llllllllll}0 & 20 & 40 & 60 & 80 & 100 & 120 & 140 & 160 & 180\end{array}$

C) Model resistivity with topography Longitudinal Profile, 13.12.2005

Iteration 6 Abs. error $=7.9$

620

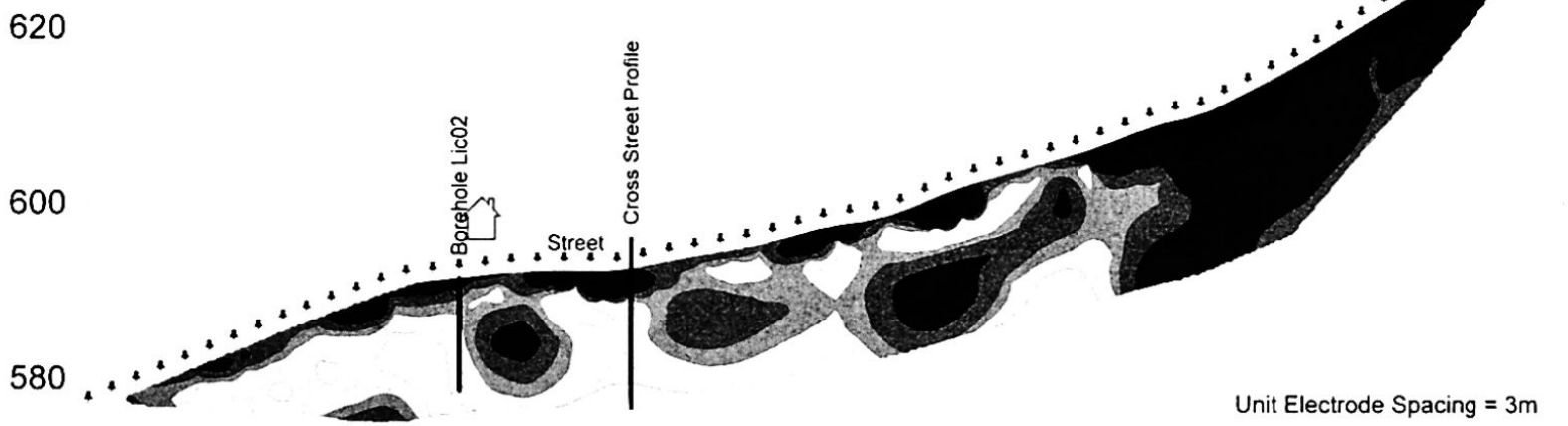

0

20

40

60

80

100

$140 \quad 160$

d) Model resistivity with topography Longitudinal Profile, 13.12.2005 Iteration 6 Abs. error $=6.0$

620

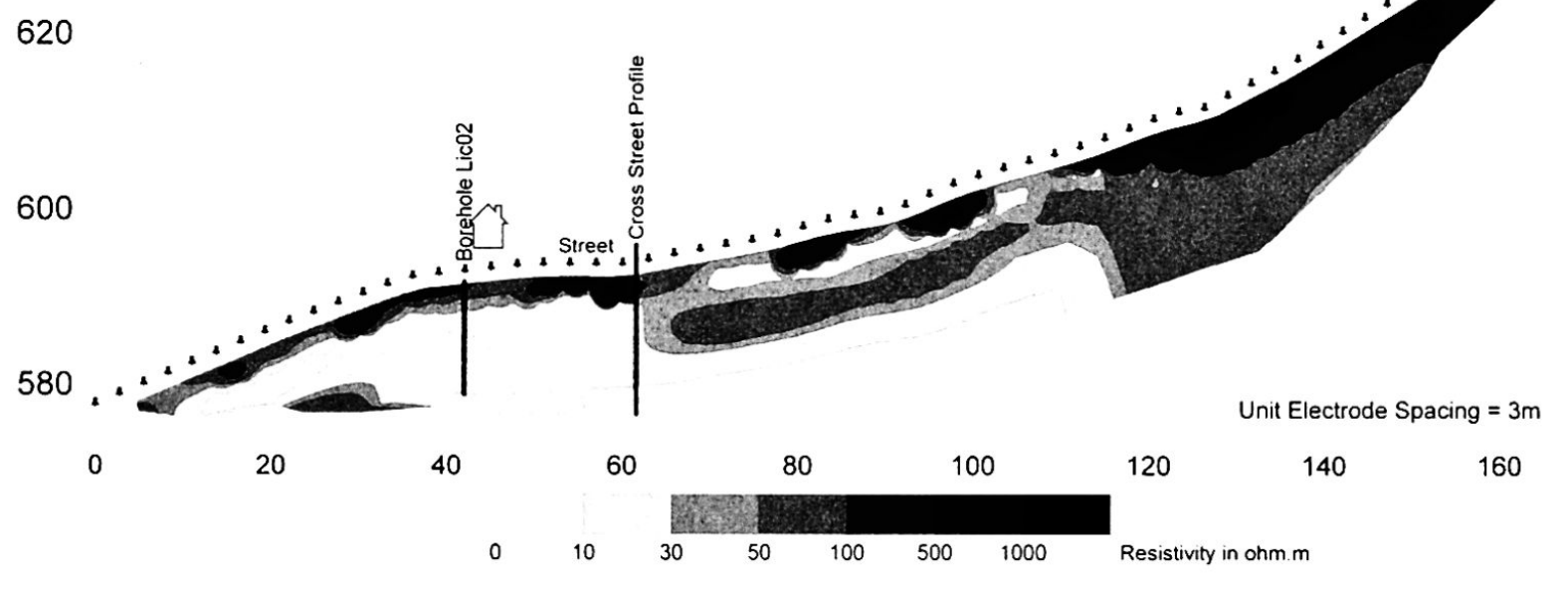

Fig. 3: 2D resistivity profiles: a) Forest Profile 1, b) Forest Profile 2, c) Longitudinal Profile 1a, d) Longitudinal Profile $1 \mathrm{~b}$

2D-Geoelektrikprofile: a) Waldprofil 1, b) Waldprofil 2, c) Längsprofil 1a, d) Längsprofil $1 \mathrm{~b}$

Profils 2D de résistivité: a) Profil forestier 1,b) Profil forestier 2, c) Profil longitudinal la, d) Profil longitudinal $1 b$ Graphics: J.-E. KRUSE, R. BELL 
Forest Profile 1, are only found at certain points. High resistivity values dominate, indicating that many more limestone blocks can be found within the old landslide body than initially measured. Unfortunately, no clear sliding plane could be detected.

Longitudinal Profile 1a shows nicely the higher resistivity of the talus slope, which mainly consists of limestone debris (Fig. 3c). However, the talus thickness could not be defined satisfactorily, ranging from 5$8 \mathrm{~m}$ to $15 \mathrm{~m}$. Further downslope, the limestone blocks appear to be smaller. From profile meter 54-60, the road causes high resistivity values for the first 2 to $3 \mathrm{~m}$. The three disconnected blocks in the central part of the profile could point to parts of old landslide masses. It is assumed that lower resistivity values between these blocks indicate areas of high moisture content. In this scenario, the sliding plane was established at a depth of $15 \mathrm{~m}$.

When interpreting resistivity data, it should be kept in mind that inversion parameters can be changed and further information included. Thus, a second run-through of the inversion routine was carried out, using a priori information, robust filtering and enhancing horizontal features (Longitudinal Profile 1b). The different results of the two longitudinal profiles are shown in Fig. 3d. The greatest difference between them appears to be in the deeper layers of the profiles. For the constrained inversion routine (1b), clear boundaries for the talus slope (7-8 m thick) as well as for the landslide mass (11-12 m thick) could be identified. Furthermore, the relevant RMS-error is smaller here than for the standard inversion routine (1a). Although this is generally positive, it does not necessarily mean that the constrained inversion result is more reliable.

\section{Discussion}

The resistivity differences between the two forest profiles are at times greater than $1000 \Omega \mathrm{m}$. This enormous range is mainly caused by changes in the moisture regime. The April measurement was heavily influenced by extensive and exceptional snow melting in spring of 2005. However, it is surprising that the high resistivity values taken to indicate limestone blocks were significantly lowered during a period of high moisture content. One explanation is that the permeability of the limestone blocks is such that percolation is intensified when enough water is available. Despite these uncertainties, the results confirm the possibility of monitoring soil moisture conditions in landslides using DC resistivity.

Like in most modelling studies, it is often possible to fit the data to an already existing geological model.
This is exemplified by the longitudinal profiles to some degree. However, fitting results to a pre-existing model does not necessarily lead to a more realistic model. In the case described herein, the sliding plane and the loose material/bedrock inferface could not be ultimately determined using geoelectric resistivity and limited borehole information alone. Even where borehole information (Lic02) was available, the bedrock could not be detected. This could be due to the high clay content $(30-70 \%)$ within the old landslide mass, the resistivity properties thereof being too similar to the bedrock. Thus, a multi-geophysical approach does appear necessary. Неснт (2003), for example, was able to detect sliding plane and bedrock interface using seismic refraction in a similar geological setting.

\section{Conclusion}

In this study, it was shown that geophysical methods are valuable tools for the extraction of information about the subsurface. Although the extent of the landslide investigated herein could not be determined fully, the suitability and limitations of certain resistivity methods could be demonstrated. It may be concluded that decisions about choice of geophysical method should be made on a case-to-case basis, taking individual landslide characteristics into account, as a one-time successful application in a particular area does not guarantee continued success, even if used in the same area for landslides within a similar geological context.

It is foreseen to continue monitoring water content within the landslide using 2D resistivity tomography at least on a monthly basis. The results will hopefully contribute towards a better understanding of different types of recent landslide activities. Furthermore, by comparing the resistivity results with rainfall totals and movement measured through inclinometers, it may be possible to determine critical moisture levels. This could contribute towards the development of early warning systems for landslides using geoelectrical methods.

\section{Acknowledgments}

This research was funded by the German Research Foundation (Deutsche Forschungsgemeinschaft - DFG; project GL 347/3). The data were provided by the State Institute for Environmental Protection (Landesanstalt für Umweltschutz - LfU) and the Ministry of Environment and Transport Baden-Württemberg.

\section{References}

Bichler, A., Bobrowsky, P., Best, M., Douma, M., Hunter, J., Calvert, T. \& R. Burns (2004): Three- 
dimensional mapping of a landslide using a multi-geophysical approach: the Quesnel Forks landslide. - In: Landslides 1, 1:29-40.

Bogoslovsky, V.A. \& A.A. Ogilvy (1977): Geophysical methods for the investigation of landslides. - In: Geophysics 42, 3: 562-571.

BouILlon, A.-L. (2005): Geophysics for geohazards on land: state-of-the-art, case studies and education. - = ICG Report No. 2005-T1-1; NGI Report No. 200511081, International Centre for Geohazards, Norwegian Geotechnical Institute, Oslo.

Cutlac, O.N. \& J.M. Maillol (2004): Study of Holocene landslide deposits by comparison of GPR, refraction seismic and electrical resistivity data. - Proceedings of the Tenth International Conference on Ground Penetrating Radar, 21-24 June 2004, Delft, The Netherlands.

Del Gaudio, V., Wasowski, J., Pierri, P., Mascia, U. \& G. CALCAGNILE (2000): Gravimetric study of a retrogressive landslide in southern Italy. - In: Surveys in geophysics 21, 4: 391-406.

Denness, B., Convay, B.W., McCann, D.M. \& P. GraINGER (1975): Investigation of a coastal landslip at Charmouth, Dorset. - In: Quaterly journal of engineering geology 8: 119-140.

Dongus, H. (1977): Die Oberflächenformen der Schwäbischen Alb und ihres Vorlandes. $-=$ Marburger geographische Schriften 72, Marburg.

Donnelly, L.J., Culshaw, M.G., Hobbs, P.R.N., Flint, R.C. \& P.D. JACKSON (2005): Engineering geological and geophysical investigations of a slope failure at Edinburgh Castle, Scotland. - In: Bulletin of engineering geology and the environment 64, 2: 119-137.

Glade, T., Stark, P. \& R. Dikau (2005): Determination of potential landslide shear plane depth using seismic refraction - a case study in Rheinhessen, Germany. - In: Bulletin of engineering geology and the environment 64: 151-158.

HACK, R. (2000): Geophysics for slope stability. - In: Surveys in geophysics 21, 4: 423-448.

Hanafy, S. \& S.A. al Hagrey (2006): Ground-penetrating radar tomography for soil-moisture heterogeneity. - In: Geophysics 71, 1: K9-K18.

Hecht, S. (2003): Differentiation of loose sediments with seismic refraction methods - potentials and limitations derived from case studies. - In: Zeitschrift für Geomorphologie, N.F., Supplementband 132: 89-102.

Knödel, K., Krummel, H. \& G. Lange (1997): Geophysik. - = Handbuch zur Erkundung des Untergrundes von Deponien und Altlasten 3, Heidelberg: Springer-Verlag.

Lapenna, V., Lorenzo, P., Perrone, A., Piscitelli, S., Rizzo, E. \& F. Sdao (2005): 2D electrical resistivity imaging of some complex landslides in the Lucanian Apennine chain, southern Italy. - In: Geophysics 70, 3: B11-B18.

LoKe, M.H. \& R.D. BARKer (1995): Least-squares deconvolution of apparent resistivity pseudosections. - In: Geophysics 60, 6: 1682-1690.

McCANN, D.M. \& A. Forster (1990): Reconnaissance geophysical methods in landslide investigations. - In: Engineering geology 29, 1: 59-78.

REYNOLDS, J.M. (1997): An introduction to applied and environmental geophysics. - Chichester: John Wiley \& Sons.

Roch, K.-H., Chwatal, W. \& E. BRÜCKL (2005): Potentials of monitoring rock fall hazards by GPR: considering as example the results of Salzburg. - In: Landslides 00: $1-8$.

Sass, O., Bell, R. \& T. Glade: Comparison of georadar, 2D resistivity and traditional techniques for the subsurface exploration of landslides. - In: Geomorphology (forthcoming).

Schmutz, M., Albouy, Y., Guérin, R., Maquaire, O., VASSAL, J., SchotT, J.-J. \& M. Descloîtres (2000): Joint electrical and time domain electromagnetism (TDEM) data inversion applied to the super sauze earthflow (France). - In: Surveys in geophysics 21, 4: 371-390.

Schrotr, L., HöRdT, A. \& R. DikAU (eds) (2003): Geophysical applications in geomorphology. $-=$ Zeitschrift für Geomorphologie, Supplementband 132, Berlin, Stuttgart: Gebrüder Borntraeger.

SuZuKI, K. \& S. Higashi (2001): Groundwater flow after heavy rain in landslide-slope area from 2-D inversion of resistivity monitoring data. - In: Geophysics 66, 3: 733-743.

\section{Abstract: Subsurface investigations of landslides using geophysical methods - geoelectrical applica- tions in the Swabian Alb (Germany)}

Landslides occur frequently all over the world, causing at times considerable economic damage, injuries and even death. In order to improve hazard assessment, common landslide types of a given region need to be investigated in detail. While traditional techniques of subsurface investigation are expensive and only provide point information, geophysical methods are suitable tools for gathering $2 \mathrm{D}$ and $3 \mathrm{D}$ information on the subsurface quickly, reliably and cost-effectively.

In this study, the suitability and limitations of 2D resistivity for the determination of landslide extent, structure and soil moisture conditions are presented. For this purpose, two identical profiles were taken during a two-month period. Significant differences in electrical resistivity $(>1000 \Omega \mathrm{m})$ due to varying soil moisture conditions were observed. Using various inversion parameters, it was possible to model two distinct subsurface images. Regrettably, the sliding plane could not be detected reliably, possibly due to the homogeniety of the landslide material and underlying bedrock. 
Erkundung des Untergrunds von Hangrutschungen unter Verwendung von geophysikalischen Methoden - geoelektrische Anwendungen in der Schwäbischen Alb (Deutschland)

Gravitative Massenbewegungen treten häufig und weltweit verbreitet auf. Sie verursachen hohe ökonomische Schäden und fordern zahlreiche Tote. Um Gefahrenanalysen zu verbessern, sollten die für eine Region charakteristischen gravitativen Massenbewegungstypen im Detail untersucht werden. Während traditionelle Techniken sehr teuer sind und nur punktuelle Informationen liefern, stellen geophysikalische Methoden geeignete Techniken dar, um schnell, günstig und zuverlässig $2 \mathrm{D}$ - und $3 \mathrm{D}$-Informationen über den Untergrund zu erhalten.

In dieser Studie werden die Möglichkeiten und Limitierungen der 2D-Geoelektrik hinsichtlich der Bestimmung der Grenzen, Struktur und Bodenfeuchtigkeitsverteilung einer gravitativen Massenbewegung untersucht. Zwei Aufnahmen von identischen Profilen zeigen aufgrund der unterschiedlichen Bodenfeuchtebedingungen enorme Veränderungen in den elektrischen Widerständen $(>1000 \Omega \mathrm{m})$ innerhalb von zwei Monaten. Die Verwendung unterschiedlicher Inversionsparameter ermöglichte zwei verschiedene Abbildungen des Untergrunds. Leider konnte die Gleitfläche nicht verlässlich bestimmt werden. Es wird angenommen, dass die Rutschmasse und das darunter liegende Festgestein ähnliche Eigenschaften aufweisen.

\section{Etudes de subsurface des glissements de terrain à l'aide de méthodes géophysiques. Applications géo- électriques dans l'Alb souabe (Allemagne)}

Les glissements de terrain sont des phénomènes fréquents qui causent des dommages économiques et font des victimes dans le monde entier. Dans le but d'améliorer l'estimation du risque lié à ce genre de phénomènes, une étude des différents types de glissements doit être menée. Alors que les techniques traditionnelles d'investigation de subsurface sont onéreuses et ne fournissent que des informations ponctuelles, les méthodes géophysiques sont des outils adéquats qui permettent de collecter des informations en $2 \mathrm{D}$ et 3D de la subsurface de façon rapide, peu onéreuses et fiable.
Cette étude présente les potentiels et les limitations de la résistivité 2D utilisée pour déterminer l'extension, la structure et les conditions hydrogéologiques. Deux profils identiques mesurés sur une période de deux mois montrent une importante différence de résistivités électriques $(>1000 \Omega \mathrm{m})$, essentiellement due à la variation de teneur en eau du sol. Utilisant divers paramètres d'inversion, deux images distinctes ont pu être obtenues, sans toutefois que la surface de glissement puisse être détectée de façon précise, ce qui laisse penser que les propriétés du matériel constituant le glissement de terrain et de la roche sous-jacente sont homogènes.

Dipl.-Geogr. Rainer Bell, PD Dr. Thomas Glade, JanErik Kruse, Geographisches Institut, Universität Bonn, Meckenheimer Allee 166, D-53115 Bonn, Germany.

e-mail:

rainer@giub.uni-bonn.de

thomas.glade@uni-bonn.de

j-e.kruse@gmx.de

Dipl.-Phys. Alejandro Garcia, Institut für Geologie, Fachbereich Geophysik, Universität Bonn, Nussallee 8, D-53115 Bonn, Germany.

e-mail: jodidocorreo@yahoo.com

Prof. Dr. Andreas Hördt, Institut für Geophysik und extraterrestrische Physik, Technische Universität Braunschweig, Mendelssohnstrasse 3, D-38106 Braunschweig, Germany.

e-mail: a.hoerdt@tu-braunschweig.de

Manuskripteingang/received/manuscrit entré le 13.1.2006

Annahme zum Druck/accepted for publication/accepté pour l'impression: 14.9.2006 